\title{
Polyphase Neoproterozoic orogenesis within the East Africa-Antarctica Orogenic Belt in central and northern Madagascar.
}

\author{
R.M.Key ${ }^{1 *}$, P.E.J.Pitfield ${ }^{2}$, R.J. Thomas², K.M. Goodenough ${ }^{1}$, B. De Waele ${ }^{3}$, D.I. Schofield ${ }^{2}$, W. \\ Bauer $^{1}$, M.S.A Horstwood ${ }^{4}$, M.T. Styles², J. Conrad ${ }^{5}$, J. Encarnacion ${ }^{5}$, D.J. Lidke ${ }^{5}$, E.A. O’Connor ${ }^{2}$, \\ C. Potter ${ }^{5}$ R.A.Smith ${ }^{1}$, G.J. Walsh ${ }^{5}$, A. V. Ralison ${ }^{6}$, T. Randriamananjara ${ }^{6}$, J-M. Rafahatelo ${ }^{6}$ and M. \\ Rabarimanana $^{6}$.
}

1 BGS, West Mains Road, Edinburgh, EH9 3LA, Scotland

2. BGS, Keyworth, Notts NG12 5GG, England

3. SRK Consulting, 10 Richardson Street, West Perth, WA 6005, Australia

4. NIGL, Keyworth, Notts NG12 5GG, England

5. USGS, Reston, Va, 20192, USA 2. BGS, Keyworth, Notts NG12 5GG, England

6. Projet de Gouvernance des Ressources Minières, Antananarivo, Madagascar

*Corresponding author (e-mail :rmk@bgs.ac.uk)

\section{Abstract}

Our recent geological survey of the basement of central and northern Madagascar allowed us to reevaluate the evolution of this part of the East Africa-Antarctica Orogen (EAAO). Five crustal domains are recognised, characterised by distinctive lithologies and histories of sedimentation, magmatism, deformation and metamorphism, and separated by tectonic and/or unconformable contacts. Four consist largely of Archaean metamorphic rocks (Antongil, Masora and Antananarivo Cratons, Tsaratanana Complex). The fifth (Bemarivo Belt) comprises Proterozoic meta-igneous rocks. The older rocks were intruded by plutonic suites at about $1000 \mathrm{Ma}$, and at 820 to $760 \mathrm{Ma}, 630$ to $595 \mathrm{Ma}$ and 560 to 520 Ma. The evolution of the four Archaean domains and their boundaries remains contentious, with two end-member interpretations evaluated: 1) all five crustal domains are separate tectonic elements, juxtaposed along Neoproterozoic sutures; 2) the four Archaean domains are segments of an older Archaean craton, which was sutured against the Bemarivo Belt in the Neoproterozoic Rodinia fragmented during the early Neoproterozoic with intracratonic rifts that sometimes developed into oceanic basins. Subsequent mid-Neoproterozoic collision of smaller cratonic blocks was followed by renewed extension and magmatism. The global 'Terminal PanAfrican' event (from 560 to $490 \mathrm{Ma}$ ) finally stitched together the mid-Neoproterozoic cratons to form Gondwana.

Number of words: 9087; number of references: 76; Number of tables: 2; number of figures: 7

Abbreviated title: Neoproterozoic orogenesis in central and northern Madagascar. 
The supercontinent of Rodinia was created by about 1.0 Ga following end-Mesoproterozoic orogenesis along a global network of Grenville-Kibaran-Namaquan orogenic belts (e.g. Torsvik et al. 1996; Dalziel 1997; Kröner 2001; McCourt et al. 2006; Li et al. 2008). Within about 120 million years of its creation, extensional rift basins started to develop, and in some instances progressed into oceanic basins, partially fragmenting Rodinia into separate crustal plates by middle Neoproterozoic times (Unrug 1998; Li et al. 2008; Wendorff \&Key 2009). Middle Neoproterozoic plate collision and subsequent extension was followed by multiple collisions of smaller crustal plates between about 560 and 520 Ma to form the Gondwana supercontinent (Meert 2003; Collins \&Pisarevsky 2005; Bingen et al. 2009). The end-Neoproterozoic-Cambrian collisional tectonics resulted in a network of linear orogenic belts, referred to as "Pan-African" in Africa (Kennedy 1964; Stern 1994; Michard et al. 2008; Gasquet et al. 2008), including the East Africa-Antarctica Orogenic Belt (EAAO) that can be traced southwards from Arabia through eastern and southern Africa, India, Madagascar and Sri Lanka into Antarctica (Jacobs \&Thomas 2004; Figure 1). Post-collision retrograde metamorphism and shearing continued into Ordovician times (to about 500 Ma; Emmel et al. 2006).

Recent work has shown that whilst all parts of the EAAO shared a common end-Proterozoic to earliest Ordovician geological history (Meert 2003; Collins \& Pisarevsky 2005; Bingen et al. 2009), the earlier Neoproterozoic tectonothermal events, at about. 820 - 720 Ma and about 660 - 610 Ma recognised in East Africa, Arabia, Madagascar and Antarctica, are less uniformly within the EAAO (Stern 1994; Meert 2003). We use the phrase 'terminal Pan-African' to describe events that took place in the 560-490 Ma period, following the original definition of Kennedy (1964). It corresponds to the "Kuunga Orogeny" resulting from India-Australia collision (Meert 2003) and the "Malagasy Orogeny" caused by India-East Africa collision (Collins \& Pisarevsky 2005). The events that make up the wider EAAO have been attributed to progressive closure of a "Mozambique Ocean” involving collisions between arc terranes and accretion of microcontinents onto East Africa (Meert 2003; Collins 2006), culminating in the final assembly of all the components of Gondwana during the terminal Pan-African (e.g. Jacobs et al. 1998; 2003; Hanson 2003; Meert 2003; Boger \& Miller 2004; Collins \& Pisarevsky 2005; Johnson et al. 2005).

Early geological work in Madagascar showed that the crystalline basement comprises a number of major crustal segments separated by tectonic contacts and unconformable boundaries (e.g. Besairie 1968-1971; Jourde 1971; Hottin 1969, 1976). Subsequent research confirmed the presence of Archaean crustal components, a range of Proterozoic supracrustal sequences, and major periods of Proterozoic reworking, and interpreted the geology in plate tectonic terms (e.g. Windley et al. 1994; Cox et al. 1998; Tucker et al. 1997, 1999a, 2010; Kröner et al. 2000; Collins et al. 2000; Collins \& Windley 2002; Collins 2006). The principal tectonic blocks identified in the central-north area include the Archaean Antongil-Masora and Antananarivo Cratons and Tsaratanana Complex, the 
Neoproterozoic Bemarivo Belt, and the Itremo Domain comprising Proterozoic metasedimentary rocks (Figure 2; Kröner et al. 2000; Collins et al. 2000; Collins \& Windley 2002; Collins 2006).

\section{The present study}

The work presented here is a summary of a 4-year World Bank funded project fully reported in BGSUSGS-GLW (2008) that allowed us to redefine the tectonic domains of north-central Madagascar and their boundaries. Following previous studies, we recognise four distinct Archaean domains (Antongil, Masora and Antananarivo Cratons, and Tsaratanana Complex) and the Neoproterozoic Bemarivo Belt in the north, along with a number of Proterozoic metasedimentary units. The domains are separated by ductile shear zones (Figure 2) and wide Neoproterozoic belts - including the "Betsimisaraka Suture" of previous authors (Kröner et al. 2000; Collins et al. 2000), which has now been mapped in greater detail and separated into two belts that are structurally continuous but have rather different characteristics; the Anaboriana and Manampotsy Belts.

We define Neoproterozoic periods dominated by extensional tectonics, with resulting magmatism and sedimentation, and intervening periods of compression, leading to plate collision and uplift, based on new and existing geochronological data (Tables 1 and 2). These are reported in a number of recently published articles on specific aspects of the geology (e.g. Thomas et al. 2009; Goodenough et al. 2010; Tucker et al. 2010; Schofield et al. in press; de Waele et al. 2008; Pitfield et al. submitted) under the umbrella of the project report (BGS-USGS-GLW 2008). The aim of this paper is to draw all the available data together into a consistent new model for the evolution of central-northern Madagascar, and its bearing on the evolution of the EAAO as a whole.

\section{Crustal Domains of central and northern Madagascar}

\section{Antongil and Masora Cratons}

Two separate, but previously correlated, Archaean crustal blocks are recognised in eastem Madagascar, known as the Antongil and Masora Cratons in the north and south respectively (Hottin, 1976; Collins \& Windley, 2002). They are separated by high-grade Neoproterozoic rocks belonging to the Manampotsy Belt (see below) and our geological mapping has recognised significant differences in the gross lithological make-up of these two cratons. The Masora Craton is also cut by c. 800 Ma granitoids not present in the Antongil Craton.

\section{Antongil Craton}

The northem part of the Antongil Craton is dominated by voluminous, largely unfoliated, Neoarchaean granitoids (Masoala Suite) formed at about 2550-2520 Ma (Tucker et al. 1999, 2010; Collins et al. 2001; Paquette et al. 2003; Schofield et al. in press). To the south there is a core of older MesoPaleoarchaean gneisses (Nosy Boraha Suite) which were formed between about 3.3 and $3.1 \mathrm{Ga}$ (Vachette \& Hottin 1970; Tucker et al. 1999, 2010; Schofield et al. in press). These are interfolded 
with Meso-Neoarchaean supracrustal rocks (Mananara Group) dated at between about $3176 \mathrm{Ma}$ and 2597 Ma (Figure 3). The latter include strongly foliated metabasic rocks and paragneisses, which occur as lenses within the southern granitoids.

The northern part of the Antongil Craton was intruded at about 2150 Ma by a number of minor metabasic sheets and podiform bodies (Ankavanana Suite: Schofield et al. in press). Previously, Hottin (1969) describes metasedimentary rocks in the Anjiahely belt in the northern Antongil Craton with many aligned meta-ultramafic lenses of harzburgite, pyroxenite, tremolite-actinolite rocks and soapstone. ). The northern margin of the craton is overthrust by the Neoproterozoic Bemarivo Belt (Thomas et al. 2009) and locally unconformably overlain by a low-grade metasedimentary sequence of possible Palaeoproterozoic age (Andrarona Group: Hottin, 1976). No Neoproterozoic to Cambrian intrusions have been recognised in the Antongil Craton which is only marginally affected by PanAfrican events and structures (Table 2).

\section{Masora Craton}

In central-east Madagascar, the Masora Craton, in similar fashion to the Antongil Craton, comprises a core of Mesoarchaean Nosy Boraha migmatitic orthogneisses with infolds of undated metavolcanosedimentary rocks (Vohilava Group: Figure 4). Another metasedimentary sequence (Maha Group) crops out around the western and northern margins of the Masora Craton. A maximum age of about $1740 \mathrm{Ma}$ is provided for the Maha Group by the youngest age of its detrital zircon population (De Waele et al. 2008). These rocks were intruded at 840-815 Ma and 780-760 Ma by voluminous Neoproterozoic granitoid sheets (Imorona-Itsindro Suite). Larger intrusions of the latter help define regional folds that range from open in form in the centre of the craton to tight dome-and-basin interference structures along the western and northern margins (Figure 4). The observed deformation in these Neoproterozoic intrusions, together with metamorphic ages recorded in zircon grain rims (Table 2) demonstrates that the whole Masora Craton was affected by the terminal Pan-African tectonothermal episode, in contrast to the Antongil Craton. However, earlier recumbent folds and associated thrusts are present to juxtapose low grade metasedimentary rocks with high-grade migmatitic gneisses (e.g. La Roche, 1953). In such zones, normal and inverted metasedimentary sequences are identified from preserved way-up structures to define recumbent folds. Some parts of the metasedimentary sequences appear to be floored by mafic-ultramafic rocks and are thought to represent thrust klippen. The preservation of low metamorphic grade rocks shows that the PanAfrican metamorphism was not as intense as found in the adjacent Manampotsy Belt. The age of the early recumbent folds is not known; they could be early Pan-African structures or older (?Mesoproterozoic). 


\section{Antananarivo Craton}

The Antananarivo Craton, which underlies the central highlands of Madagascar, comprises granuliteto upper amphibolite facies Neoarchaean orthogneisses and paragneisses (Figure 5). No evidence for Mesoarchaean rocks have been found, in contrast to the Antongil and Masora Cratons. Extensive tracts of Neoarchaean/earliest Palaeoproterozoic tonalitic to granitic gneisses (Betsiboka Suite: Mangoro Complex) have been dated at about 2490 - 2590 Ma (Tucker et al. 1999a; Kröner et al. 2000; BGS-USGS-GLW, 2008). These are intimately associated with supracrustal rocks, chiefly migmatitic paragneisses (Vondrozo and Sofia Groups), which form extensive belts (e.g. Sofia Group) or isolated rafts in the orthogneisses. The Vondrozo and Sofia Groups are thus demonstrably Archaean, but there are no constraints on their maximum depositional ages.

In central-west Madagascar, the Antananarivo Craton is overlain by Proterozoic metasedimentary rocks of the Itremo, Molo, and Amborompotsy-Ikalamavony Groups in the Itremo Domain. These correlated rocks, of different metamorphic grades, are characterised by significant detrital zircon peaks at about 2500 and 1800 Ma (Cox et al. 1998, 2004; Fitzsimons \& Hulscher, 2005; Tucker et al. 2007; De Waele et al. 2008). The relationship between them and the underlying craton is unclear. Collins et al. (2000) recognised a major shear zone forming the contact in some parts, whilst elsewhere the contact appears unconformable (Collins, 2006; Tucker et al. 2007).

The Antananarivo Craton and the Itremo Domain are intruded by voluminous Neoproterozoic to Cambrian plutonic rocks. The oldest of these (Dabolava Suite orthogneisses), intruded the Itremo Group at about1000 Ma (Tucker et al. 2007). Subsequently, plutons of the Imorona-Itsindro Suite, which intrude the whole Antananarivo-Itremo block, have been dated between about 840 and $720 \mathrm{Ma}$ (Handke et al. 1999; Tucker et al. 1999a; Kröner et al. 2000; BGS-USGS-GLW, 2008). In addition, the northern part of the craton was intruded by sheet-like, alkaline 'stratoid granites' (Kiangara Suite) at about 630 Ma (Nédélec et al. 1995; Paquette \& Nédélec, 1998), and post-collisional granitoids (e.g. Ambalavao and Mahamavy Suites and Carion Subsuite) during the period 550 - 530 Ma (Tucker et al. 1999a; Kröner et al. 1999, 2000; Meert et al. 2001; Goodenough et al. 2010).

The Antananarivo Craton is characterised by a penetrative, north- to NNW-trending structural grain, marked by parallel ortho- and paragneiss belts. The highest strain is recognised in the east, along the Angavo-Ifanadiana Shear Zone that cuts into the craton from the Manampotsy Belt (Figure 2; Nédélec et al. 2000). Heat transfer associated with rise of magma and fluids along this shear zone continued until about 470 Ma (Grégoire et al. 2009).

\section{Tsaratanana Complex}

The Tsaratanana Complex, which overlies the northern part of the Antananarivo Craton, comprises three main infolded synformal belts (Figure 2: Maevatanana, Andriamena and Alaotra-Beforona; Tucker et al. 1999a; Collins \& Windley, 2002; Collins, 2006). Each is dominated by Neoarchaean 
orthogneisses, pelitic schists, and paragneisses that have previously been interpreted as greenstone belts (de Wit, 2003). The orthogneisses include gabbroic, tonalitic and granodioritic compositions, and have been dated at about 2520-2470 Ma (Tucker et al. 1999; Kabete et al. 2006; BGS-USGSGLW, 2008) with evidence for high-temperature metamorphism of some at about $2500 \mathrm{Ma}$ (Gonçalves et al. 2003; Tucker et al. 2010). However, a paragneiss from the Andriamena Belt contained detrital zircons in the range 2870 to $1750 \mathrm{Ma}$, suggesting the presence of Palaeoproterozoic or younger material (Kabete et al. 2006).

In common with the Antananarivo-Itremo block, the Tsaratanana Complex is intruded by gabbroic and granitoid plutons of the Neoproterozoic Imorona-Itsindro Suite (Guérrot et al. 1993; Tucker et al. 1999; Kabete et al. 2006; BGS-USGS-GLW 2008). High-grade metamorphism is also recorded in the Andriamena Belt at about 780 - 730 Ma (Gonçalves et al. 2003; Kabete et al. 2006; BGS-USGSGLW 2008).

The Tsaratanana Complex is separated from the underlying rocks by flat-lying to sub-vertical ductile shears with complex polyphase and polydirectional movement histories (Gonçalves et al. 2003; BGSUSGS-GLW 2008). Moreover, the BGS-USGS mapping has shown that parts of the Tsaratanana Complex tectonically overlie not only the Antananarivo Craton, but also the Neoproterozoic Manampotsy Belt (Figure 5). This observation has critical implications for the timing of emplacement of the Tsaratanana Complex and supports the conclusion of Kröner et al. (2000) that (at least some of) the complex is an allochthonous unit and not an integral part (e.g. greenstone belt) of the Antananarivo Craton. However, the precise timing of the final horizontal translation of the Tsaratanana Complex remains uncertain. Although the last period of movement probably occurred in the early Cambrian (Gonçalves et al. 2003), at least parts of the Tsaratanana Complex were juxtaposed with the underlying combined Antananarivo-Itremo block before the intrusion of the Imorona-Itsindro Suite (Tucker et al. 2010).

\section{Bemarivo Belt}

The Neoproterozoic Bemarivo Belt forms the most northerly crustal entity of Madagascar, where it is tectonically juxtaposed against the Antongil and Antananarivo Cratons and the Neoproterozoic Anaboriana Belt (Collins \& Windley, 2002; Collins, 2006; Thomas et al. 2009). It is divided into northern and southern terranes which, on the basis of lithostratigraphy and geochronology, are considered to have formed in volcanic arc settings at about 715 and 750 Ma respectively (Thomas et al. 2009).

The northern terrane comprises three volcano-sedimentary successions: the upper amphibolite-facies Milanoa Group, the greenschist-facies to epidote-amphibolite-facies Daraina Group, and the Betsiaka Group with measured PT conditions of $12 \mathrm{~kb}$ and $650^{\circ} \mathrm{C}$ (BGS-USGS-GLW 2008). The first two were derived from Neoproterozoic, probably juvenile, sources, whilst the Betsiaka Group contains 
Archaean detrital zircons (Thomas et al. 2009). This terrane is intruded by the plutonic Manambato Suite, dated between 718 and 708 Ma (Tucker et al. 1999b; Thomas et al. 2009).

The southern terrane is dominated by the granulite facies metasedimentary Sahantaha Group, consisting of quartzites, calc-silicate and metapelitic rocks. Samples from this group have yielded detrital zircon age spectra with ages ranging from about 2800 to $1750 \mathrm{Ma}$, with the largest peak in the Palaeoproterozoic (Cox et al. 2004; De Waele et al. 2008). These rocks are intruded by the calcalkaline plutonic Antsirabe-Nord Suite which was emplaced at about 750-760 Ma (Tucker et al. 1999b; Thomas et al. 2009). Hottin (1969) suggested that the Sahantaha metasedimentary rocks rest unconformably on high grade 'basement' rocks. However, exposed contacts noted between the Sahantaha Group and other rocks including Antongil Craton rocks were ubiquitously tectonic (BGSUSGS-GLW 2008; Thomas et al. 2009).

High-grade metamorphism in the southern terrane of the Bemarivo Belt has been dated at about 560530 Ma (Jöns et al. 2006; Table 2) and this is considered to represent the timing of collision of the Bemarivo Belt with the previously amalgamated older 'core' of Madagascar (Jöns et al. 2006; Thomas et al. 2009). Both terranes of the Bemarivo Belt, and the Anaboriana Belt to the south, were intruded by voluminous, post-collisional, A-type granitoids (Maevarano Suite) at about 540-520 Ma (Buchwaldt et al. 2003; Goodenough et al. 2010).

\section{Anaboriana and Manampotsy Belts}

The north-south trending Anaboriana and Manampotsy Belts (Figure 2) are redefined tectonostratigraphic domains which together broadly correspond to the Betsimisaraka Suture Zone (Kröner et al. 2000; Collins \& Windley, 2002). In the NW, the Anaboriana Belt separates the Bemarivo Belt from the Antananarivo Craton, and is bounded by ductile shear zones. It runs southwards into the Antananarivo Craton, close to its eastern margin, and has been linked on geophysical and lithostratigraphical grounds to the Manampotsy Belt, which separates the Masora, Antongil and Antananarivo Cratons.

The main rock-types throughout the Anaboriana and Manampotsy Belts are quartzofeldspathic migmatitic paragneisses, with varying biotite and hornblende contents, although some graphitic, quartzitic and calc-silicate lithologies are locally present. In the Anaboriana Belt, the paragneisses are termed the Bealanana Group. The Manampotsy Belt paragneisses of the Manampotsy Group are divided into the Sasomanangana Gneiss, Sakanila Paragneiss, Perinet Paragneiss and Ambatondrazaka Paragneiss (Figure 6) on the basis of their dominant sedimentary protolith. The Ambatolampy Group occurs on the margin of the Antananarivo Craton, whilst the Ampasary Group crops out on the western margin of the Masora Craton, within a tectonic entity known as the "Maroala Deformation Zone” (Figures 2 and 6). This structural complex comprises a highly deformed imbricate zone, with inter-thrust slices of the Ampasary Group and Masora Craton rocks. Numerous mafic- 
ultramafic lenses in the Manampotsy Belt range from 1 to $500 \mathrm{~m}$ in length, and include harzburgite, pyroxenite and actino-tremolitite to hornblendite.

Detrital zircon populations from typical paragneiss samples in both the Manampotsy and Bealanana Groups record Neoproterozoic age peaks of 840-780 Ma, with a lead-loss event indicating metamorphism at c.560-510 Ma (BGS-USGS-GLW, 2008; Table 2). Older detrital zircons are found in samples from the craton-marginal sequences. Thus, samples from the Ampasary Group contain a range of detrital zircons from Meso- and Neoarchaean sources as well as 2000-1800 Ma and Neoproterozoic ( 800-780 Ma) grains (Collins et al. 2003; BGS-USGS-GLW, 2008). Similarly, Ambatolampy Group samples have major detrital peaks at about 2700 and 2500 Ma (BGS-USGSGLW, 2008). These data sets suggest that the original sediments of the Ampasary and Ambatolampy groups were deposited on the underlying (marginal) parts of the Masora and Antananarivo Cratons respectively, while the Manampotsy and Bealanana Groups were most likely deposited distal from either of the cratonic domains. A contrary view is presented by Tucker et al. (2010).

The Manampotsy Belt also comprises Neoproterozoic magmatic rocks that belong to the ImoronaItsindro Suite. Rapid unroofing of these intrusions may have provided source material for the spatially associated metasedimentary rocks (indicated by their detrital zircon populations). The ImoronaItsindro Suite is not present in the Anaboriana Belt, which contains large volumes of post-collisional granitoids of the Maevarano Suite, dated between about 540-520 Ma (Goodenough et al. 2010). No older, pre-Neoproterozoic magmatic rocks have been found in either the Manampotsy or Anaboriana Belts.

The Manampotsy Belt has a strong, curviplanar N-S tectonic grain defined by major polyphase shear zones with an E-W spur separating the Masora and Antongil Cratons. It includes the Maroala Deformation Zone around the western perimeter of the Masora Craton (Figures 2, 4 and 6). The western section of the Maroala Deformation Zone is cut by the southern part of the regional AngavoIfanadiana Shear Zone. Transposed north-south-oriented planar fabrics, dextral shears and polyphase folds occur in the latter which forms the highest strain tract in the Manampotsy Belt (Raharimahefa, 2004).

\section{Geotectonic evolution of central and northern Madagascar}

\section{Archaean}

The oldest rocks known in Madagascar are the Mesoarchaean orthogneisses of the Antongil and Masora Cratons, known as the Nosy Boraha Suite, and dated at about 3320-3150 Ma. Neoarchaean (about $2500 \mathrm{Ma}$ ) granitoid gneisses are a major component of the Antongil Craton. The Maha Group in the Masora Craton contains detrital zircons with ages of about $2500 \mathrm{Ma}$, providing indirect evidence for rocks of this age in that craton. It has been proposed that the Antongil Craton is a 
fragment of the Dharwar Craton of western India (Tucker et al. 1999a, 2010; Collins \& Windley, 2002; Collins, 2006; Schofield et al. in press). The presence of Meso- and Neoarchaean gneisses of similar age in both cratons, common isotopic signatures, along with their common Palaeoproterozoic igneous activity (Peucat et al. 1993; Tucker et al. 1999a, 2010; Jayananda et al. 2006; Schofield et al. in press) provides support for this correlation. The Masora Craton may originally have been part of the Antongil-Dharwar Craton, but has clearly experienced a different Neoproterozoic history.

The Antananarivo Craton and the Tsaratanana Complex are dominated by Neoarchaean gneisses, with no direct evidence for Mesoarchaean magmatism. However, Nd isotope evidence indicates that the Neoarchaean magmas were contaminated by older crustal material, thus raising the possibility that some Mesoarchaean crust may remain to be found in these domains (Tucker et al. 1999).

Metasedimentary rocks of probable Neoarchaean age are found in the Antongil Craton (the Mananara Group); the Masora Craton (the Vohilava Group); the Antananarivo Craton (the Vondrozo and Sofia Groups); and the Tsaratanana Complex. The sources of the Mananara Group appear to be broadly coeval with the extensive Meso- and Neoarchaean magmatism in the Antongil Craton. Most of the other possible Neoarchaean metasedimentary sequences have not been investigated for detrital zircons, and so the age of their sources remains uncertain.

\section{Palaeoproterozoic}

Palaeoproterozoic magmatic rocks are minor components of the Andriamena Belt (Tsaratanana Complex) and the Antongil Craton (Ankavanana Suite). Mafic dykes of very similar age are also found in the Dharwar Craton (Pandey et al. 1997), again supporting previous suggestions that the Antongil and Dharwar Cratons were once linked. However, mafic dyke intrusion of this age is a common feature of many cratons (Ernst \& Buchan, 2001).

A number of Proterozoic sedimentary sequences are recognised in Madagascar, including the Itremo, Maha and Sahantaha Groups, which have evidence for Neoarchaean to Palaeoproterozoic sources, with detrital zircon age peaks at around 2500 and 1800 Ma (Cox et al. 1998, 2004; Fitzsimons \& Hulscher, 2005; De Waele et al. 2008). The detrital zircon age spectra for the Itremo Group match potential sources in East Africa rather than India, leading to a correlation between the Antananarivo Craton and East Africa (Cox et al. 1998; Fitzsimons \& Hulscher, 2005). However, other cratons also contain magmatic rocks dated at around 2500 and 1800 Ma, so using detrital zircon ages as evidence for provenance is not valid in this case. It could also be argued that the absence of dominant amounts of 2000 Ma detrital zircons from any of the Madagascan metasedimentary sequences would suggest that their source areas were not the African cratons, where igneous rocks of this age are a significant component of the geology (e.g. Hanson, 2003; Key et al. 2001). 


\section{Neoproterozoic-Palaeozoic magmatism and orogenesis}

Following a period of apparent quiescence throughout Mesoproterozoic times, renewed tectonothermal activity in Madagascar began around 1000 Ma with the emplacement of granitoids into the Itremo Domain (Tucker et al. 2007). The nature of this early magmatism remains uncertain. Subsequently, the voluminous Imorona-Itsindro Suite was emplaced between about 840 and $720 \mathrm{Ma}$ into all crustal domains except the Anaboriana Belt, the Bemarivo Belt, and the Antongil Craton. A wide range of rock types from granitic to gabbroic orthogneisses are represented. The suite can be traced for about $450 \mathrm{~km}$ along a wide, N-S trending zone in central-northern Madagascar and has been likened to an Andean-type continental magmatic arc on petrological grounds (Handke et al. 1999; Kröner et al. 2000; Ashwal et al. 2002; de Wit, 2003). However, more geochemical work is required on this major magmatic suite as it may represent emplacement of plutons in a range of settings along one or more accretionary margins. The Manampotsy Group and associated intrusions may represent a juvenile island arc terrane formed at this time, in a basin between the Antananarivo and Masora Cratons (Figure 7). It has been argued that subsequent collision of the arc system with adjacent continents created the Betsimisaraka Suture Zone (e.g. Cox et al. 1998; Kröner et al. 2000; Collins et al. 2000; Collins \& Windley, 2002). This scenario was based on the presence of (1) metasedimentary lithologies diagnostic of a marine setting, notably graphitic gneisses; (2) abundant lenses of mafic and ultramafic rocks interpreted as slivers of oceanic crust; (3) Neoproterozoic detrital zircon ages; (4) different Archaean blocks on opposite sides of the belts; (5) meta-igneous rocks of purported suprasubduction origin (Itsindro-Imorona Suite); (6) medial Proterozoic platform sediments on the Antananarivo Craton with detrital zircons of proposed African provenance and (7) extensive PanAfrican overprinting of the Antananarivo Craton but not of the Antongil Craton.

However, whilst our work supports many of these arguments it does not supported others and we would question whether the detrital zircon data support an African provenance for the platform sediments on the Antananarivo Craton (see Tucker et al. 2010 for a fuller discourse on rebutting the existence of a suture zone). Our work also suggests that the Antananarivo and Masora Cratons share a common history prior to terminal Pan-African orogenesis, and that if they collided it took place during an earlier mid-Neoproterozoic orogenesis (Figure 7).

The Bemarivo Belt was formed as two juvenile island arc terranes between about 750 and 720 Ma (Tucker et al. 1999b; Thomas et al. 2009). Detrital zircon evidence shows that sediments in these arcs were not sourced from the older rocks of Madagascar, and thus that the arcs are considered to have formed at some distance (Thomas et al. 2009).

The Neoproterozoic metasedimentary rocks of the Manampotsy Belt, as well as successions in the Antananarivo Craton and Tsaratanana Complex, record pre-Pan-African structures related to horizontal tectonics and associated high-grade metamorphism. In the Itremo Group, early large-scale 
recumbent folds may have been formed prior to emplacement of Imorona-Itsindro suite plutons (Collins et al. 2003), although this field relationship is disputed by Tucker et al. (2007).

Extensional tectonics after about $800 \mathrm{Ma}$ led to the development of new oceanic crust, preserved in the Vohibory volcano-sedimentary succession of southern Madagascar (Collins, 2006). This event has been attributed to the rifting of a microcontinent (“Azania” from East Africa; Collins \& Pisarevsky, 2005). Subsequent collisional deformation has been recorded in southern Madagascar at about 650$610 \mathrm{Ma}$ (de Wit et al. 2001). In central Madagascar, the late stages of this event are considered to be manifested by post-collisional alkaline Kiangara Suite granites, which were emplaced into the Antananarivo and Masora Cratons and the Manampotsy Belt between about 630 and 595 Ma (Nédélec et al. 1995; Paquette \& Nédélec, 1998). This widespread, but volumetrically small, suite includes several phases of foliated, typically sheet-like alkaline granites and syenites emplaced within an 800 km long zone north and south of Antananarivo. However, the absence of metamorphic zircon ages in this age bracket (Table 2) in our study implies that there was no collisional event during this period in central and northern Madagascar.

From about $560 \mathrm{Ma}$, the major terminal Pan-African collisional event culminated in the amalgamation of the various tectonic blocks of central and northern Madagascar. Table 2 summarises the inferred ages (and PT conditions) of the Pan-African metamorphism based on U-Pb dates obtained from metamorphic rims to zircon grains (BGS-USGS-GLW, 2008). The ages confirm that the terminal PanAfrican metamorphism took place over a protracted period between about 560 and 510 Ma. This long metamorphic period reflects multi-staged collision, subsequent orogenic collapse and high heat flow associated with post-collisional granite emplacement. Estimated PT conditions suggest that amphibolite- to granulite-facies mineral assemblages were prevalent during the Pan-African events (Buchwaldt et al. 2003; Jöns et al. 2005, 2006). An initial high pressure, moderate temperature metamorphism is localised in the eastern part of the Manampotsy Belt near the tectonic boundaries with the Antongil and Masora Cratons, and in the Palaeoproterozoic supracrustal rocks (e.g. Maha Group). This metamorphism is considered to be associated with the collision of the Antongil Craton with the previously amalgamated Antananarivo and Masora Cratons. No magmatic event is recorded at this time and the emplacement of the Antongil Craton may have been along a major transcurrent ductile shear, rather than by collision across a dipping subduction zone. A later, higher temperature metamorphism, probably at lower pressures, caused the commonly seen overprint of kyanite by sillimanite, suggesting a clockwise P-T path (BGS-USGS-GLW, 2008). This event is probably associated with the high heat flow caused by the emplacement of the voluminous post-collisional granites and charnockites (Goodenough et al. 2010).

A minimum age for the amalgamation of the Antongil and Antananarivo Cratons is given by the subsequent tectonic emplacement of the Bemarivo Belt across the tectonically joined AntananarivoAntongil Cratons and the interleaved Anaboriana Belt. The emplacement of the Bemarivo Belt has 
been dated by Jöns et al. (2006) from successive monazite rims, which suggest collision at about 560530 Ma, with (post-collision) peak metamorphic conditions at about 520-510 Ma. However, Buchwaldt et al. (2003) obtained U-Pb TIMS ages on titanite, monazite and zircon from the southern Bemarivo Belt and suggested that emplacement and metamorphism took place between 520 and 510 Ma, associated with the intrusion of the voluminous post-collisional granitoids of the Maevarano Suite (Goodenough et al. 2010).

The Antongil Craton is least affected by the Pan-African event as fabrics of this age are only present along the western and southern margins (BGS-USGS-GLW, 2008; Schofield et al. in press). Metamorphic ages of about 530 Ma from these margins (Table 2) either date the docking of the Antongil Craton against the older crustal blocks or provide a minimum age for the amalgamation.

Late to post-tectonic, post-collisional granites ( 550-520 Ma; Tucker et al. 1999b; Kröner et al. 2000; Meert, 2003; Collins, 2006) are now dated at between about 537 and 522 Ma (Goodenough et al. 2010). These 'late' granites are potassic in composition, and were emplaced into a post-collisional setting, in contrast to all of the older granites that show subduction-related geochemistry.

The final phases of tectono-metamorphic activity associated with the EAAO are shown both by fission track analysis of basement rocks in central Madagascar, and by low temperature, shear controlled hydrothermal mineralisation. These data indicates that cooling from the final metamorphic overprint terminated at about $500 \mathrm{Ma}$ (Emmel et al. 2006) and (emerald) mineralisation took place at about 490 Ma (Moine et al. 2004).

\section{Discussion and conclusions}

Our geological study (BGS-USGS-GLW, 2008; Thomas et al. 2009; Goodenough et al. 2010; BGSUSGS-GLW. 2008, Tucker et al. 2010; De Waele et al. 2008; Schofield et al. in press) has confirmed that central and northern Madagascar comprises a number of distinct Archaean domains separated by wide ductile shear zones within the central part of the EAAO. Of the four Archaean domains in northcentral Madagascar, the Masora and Antananarivo Cratons appear to have different Mesoarchaean histories, but to have shared a common history since about $820 \mathrm{Ma}$, perhaps as early as the Neoarchaean (2500 Ma). The Antananarivo Craton cannot be matched with an East African craton (e.g. the Tanzania Craton) and we agree with Collins (2006) in interpreting this domain as part of a separate Azania microcontinent within the East African Orogen. The Tsaratanana Complex may originally have formed a continuous sequence that was intruded by Neoarchaean granitic rocks and subsequently tectonically transported en masse across the Antananarivo Craton, before segmentation into synformal keels and thrust slices during Pan-African times. Despite this, the similarities in the preserved Archaean histories of the Tsaratanana Complex and tectonically underlying Antananarivo Craton rocks suggests that at least parts of the former were autochthonous parts of the underlying craton. 
The Antongil Craton may have a similar Archaean history to the Masora Craton, but it lacks pervasive Neoproterozoic reworking. It thus probably only docked with the rest of Madagascar during the terminal Pan- African collision. The Bemarivo Belt clearly had a separate Neoproterozoic history as an island arc assemblage which was only amalgamated with the rest of Madagascar in the Late Neoproterozoic to early Cambrian (Thomas et al. 2009).

The status of the Anaboriana and Manampotsy Belts as a suture zone (the Betsimisaraka Suture Zone) is not fully resolved (Tucker et al. 2010). In support of the suture zone interpretation are (1) the absence of rocks older than Neoproterozoic from the belts, (2) the presence of apparently different Archaean cratons on opposite sides of the Manampotsy Belt with continental margin sediments on its eastern and western margins, (3) the presence of actively eroding Neoproterozoic magmatic arc rocks within the Manampotsy Belt, (4) tectonic slices of mafic/ultramafic rocks interpreted as remnants of oceanic crust, and (5) the 800 Ma detrital zircon population and absence of proximal Archaean crust in the central Manampotsy Group metasediments. Against the interpretation are the similar early Neoproterozoic histories of the Antananarivo and Masora Cratons on either side of the Manampotsy Belt, including the presence of intrusions of the Imorona-Itsindro Suite across the whole area. We therefore suggest that the Manampotsy Belt first developed as a pre-terminal Pan-African, preKiangara Suite collisional/suture zone between the Antananarivo and Masora Cratons. Metamorphic fabrics in the Imorona-Itsindro Suite rocks and adjacent metasedimentary rocks that developed during the collisional event are strongly overprinted by terminal Pan-African fabrics associated with the later collision between the Antongil and Masora cratons.

The Antongil Craton only collided with an amalgamated Antananarivo-Masora Craton during the terminal Pan- African. It may have been emplaced along a N-S transcurrent shear that extended into the Manampotsy Belt. Later collision occurred as the Bemarivo Belt was thrust southwards over the older terranes (Thomas et al. 2009). The Anaboriana Belt represents the suture between the Bemarivo Belt and the Antananarivo and Antongil Cratons. Terminal Pan-African orogenesis in the Manampotsy Belt involved imbrication along the western margin of the Masora craton in the Maroala Deformation Zone. Post-collisional magmatism (Goodenough et al. 2010), retrograde metamorphism and shearing continued until about $490 \mathrm{Ma}$.

It can be seen that the rocks of northern and central Madagascar record complex, polyphase orogenesis with intervening extensional phases, over a period of about 330 million years between about 820 and 490 Ma. This process may have included the creation and subsequent almost complete destruction of oceanic crust that separated the Antananarivo and Masora Cratons. Understanding the precise timing of the collisions between these different tectonic blocks relies in part on trying to date specific syn-collision igneous events or tectonic and/or metamorphic fabrics in the suture zones, and less precisely on dating the time when domains on opposite side of a suture start to share a common geological history and were thus 'docked'. In suture zones with polyphase tectono-thermal histories 
and where the final tectono-thermal event was sufficiently strong to effectively either obliterate or transpose earlier fabrics it is often difficult to precisely date older structures.

The present study supports and enlarges upon recent studies on the various Neoproterozoic-earliest Palaeozoic orogens of East Africa and Madagascar that describe the partial break-up of Rodinia into smaller continental blocks during the first half of the Neoproterozoic and the later collision of these blocks to create Gondwana by earliest Phanerozoic times (e.g. Porada \& Berhorst, 2000; Grantham et al. 2003; Johnson et al. 2007; De Waele et al. 2008; Wendorff \& Key, 2009; Bingen et al. 2009, Thomas et al. 2009). The break-up of Rodinia created a number of smaller continental blocks bounded by active and passive margins. A major magmatic arc formed after about 840 Ma to create an uplifted region that was eroded to feed sediments within the Manampotsy Belt and along the margins of the Antananarivo and Masora Cratons. The period between about 740 and $630 \mathrm{Ma}$ involved the initial collision between the Antananarivo and Masora Cratons with the development of compressional structures in the adjacent Manampotsy Belt. Subsequent extension was accompanied by the emplacement of magmatic rocks (of the Kiangara Suite) that cut across structures formed during the earlier collisions. The global terminal Pan-African orogenic event (560-490 Ma) was common to all the Neoproterozoic orogens and culminated with the amalgamation of all the disparate terrains into Gondwana. The Neoproterozoic Era has the unique distinction of recording the break-up of one super-continent and the creation of a second; both super-continents formed by contemporaneous orogenesis in a network of linear orogens. The driving force for the synchronicity of global orogenesis is not known.

\section{Acknowledgements}

The paper is published with the permissions of the Executive Director of the British Geological Survey (NERC) and the Director of the USGS. Some age data in this paper were obtained at the Perth Consortium SHRIMP facilities at the Curtin University of Technology, which are funded by the Australian Research Council. We would also thank Robert Tucker for his significant input into our Project. His different interpretation of the 'Betsimisaraka Suture Zone' as a deformed, Neoproterozoic intracratonic sequence is presented in a separate paper (Tucker et al. 2010). The authors would like to thank Professor Brian Windley and the other reviewer for their helpful comments on the original manuscript.

\section{References}

Ashwal, L D, Demaiffe, D, \& Torsvik, T H. 2002. Petrogenesis of Neoproterozoic granitoids and related rocks from the Seychelles: The case for an Andean-type arc origin. Journal of Petrology, 43, 45-83.

Besairie, H. 1968-71. Description géologique du massif ancient de Madagascar. Document Bureau Géologique Madagascar, 177. Bureau Géologique Madagascar, Antananarivo. 
BGS-USGS-GLW. 2008. Revision de la cartographie géologique et minière des zones Nord, Centre et Centre-Est de Madagascar. BGS Report CR/08/078. Keyworth, England. 1086p.

Bingen, B., Jacobs, J. Viola, G., Henderson, I.H.C. Skår, Ø. Boyd, R. Thomas, R.J., Solli, A., Key, R.M. \& Daudi, E.X.F. 2009. Geochronology of the Precambrian crust in the Mozambique belt in NE Mozambique, and implications for Gondwana assembly. Precambrian Research, 170, 231-255.

Boger, S.D. \& Miller, J.M. 2004. Terminal suturing of Gondwana and the onset of the RossDelamerian Orogeny: the cause and effect of an Early Cambrian reconfiguration of plate motions. Earth and Planetary Science Letters, 219, 35-48.

Buchwaldt, R, Tucker, R.D., \& Dymek, R.F. 2003. Geothermobarometry and U-Pb Geochronology of metapelitic granulites and pelitic migmatites from the Lokoho region, Northern Madagascar. American Mineralogist, 88, 1753-1768.

Collins, A.S. 2006. Madagascar and the amalgamation of central Gondwana. Gondwana Research, 9, 3-16.

Collins, A.S. \& Windley, B.F. 2002. The tectonic evolution of central and northern Madagascar and its place in the final assembly of Gondwana. Journal of Geology, 110, 325-340.

Collins, A.S. \& Pisarevsky, S.A. 2005. Amalgamating eastern Gondwana: the evolution of the Circum-Indian Orogens. Earth Science Reviews, 71, 229-270.

Collins, A.S, Razakamanana, T., \& Windley, B.F. 2000. Neoproterozoic extensional detachment in central Madagascar: implications for the collapse of the East African Orogen. Geological Magazine, 137, 39-51.

Collins, A.S, Fitzsimons, I.C.W., Kinny, P.D., Brewer, T.S., Windley, B.F., Kröner, A. \& Razakamanana, T. 2001. The Archaean rocks of central Madagascar: their place in Gondwana. In: CASSIDY, K.F.; DUNPHY, J.M. \& VANKRANENDONK, M.J. (eds.) Fourth International Archaean Symposium 2001, extended Abstracts. AGSO-Geoscience Australia, Record 2001/37, 294296.

Collins, A.S, Fitzsimons, I.C.W., Hulscher, B., \& Razakamanana, T. 2003. Structure of the eastern margin of the East African Orogen in central Madagascar. Precambrian Research, 123, 111-133.

Cox, R., Armstrong, R.A. \& Ashwal, L.D. 1998. Sedimentology, geochronology and provenance of the Proterozoic Itremo Group, central Madagascar, and implications for the pre-Gondwana Palaeogeography. Journal of the Geological Society, London, 155, 1009-1024.

Cox, R., Coleman, D.S., Chokel, C.B., De Oreo, S.B., Collins, A.S., Kröner, A. \& De Waele, B. 2004. Proterozoic tectonostratigraphy and paleogeography of central Madagascar derived from detrital zircon U-Pb age populations. Journal of Geology, 112, 379-400.

Dalziel, I.W.D.1997. Neoproterozoic-Paleozoic geography and tectonics: review, hypothesis and environmental speculation. Bulletin of the Geological Society of America, 109, 16-42.

De Waele, B., Johnson, S.P. \& Pisarevsky, S.A. 2008. Palaeoproterozoic to Neoproterozoic growth and evolution of the eastern Congo Craton: its role in the Rodinia puzzle. Precambrian Research, 160, 127-141.

De Waele, B., Horstwood, M.S.A., Bauer, W., Key, R.M., Pitfield, P.E.J., Potter, C.J., Rabarimana, M., Rafahatelo, J.-M., Ralison, V., Randriamananjara, T., Smith, R.A., Thomas, R.J. \& Tucker, R.D., 2008. U-Pb detrital zircon geochronological provenance patterns of supracrustal successions in central and northern Madagascar. Colloquium of African Geology, Hammamat, Tunisia, pp. 3.

De Wit, M. J. 2003. Madagascar: Heads it's a continent, tails it's an island. Annual Review of Earth and Planetary Sciences, 31, 213-248.

De Wit, M. J., Bowring, S. A., Ashwal L. D, Randrianasolo, L G, Morel, V. P. I. \& Rambeloson R. A. 2001. Age and tectonic evolution of Neoproterozoic ductile shear zones in southwestern Madagascar, with implications for Gondwana studies. Tectonics, 20, 1-45. 
Emmel, B., Jacobs, J., Kastowski, G. \& Graser, G. 2006. Phanerozoic upper crustal tectono-thermal development of basement rocks from central Madagascar: an integrated fission-track and structural study. Tectonophysics, 412, 61-86.

Ernst, R.E. \& Buchan, K.I. (eds.) 2001. Mantle Plumes: their identification through time. Geological Society of America, Special Publication, 352, 595pp.

Fitzsimons, I.C.W. \& Hulscher, B. 2005. Out of Africa: detrital zircon provenance of central Madagascar and Neoproterozoic terrane transfer across the Mozambique Ocean. Terra Nova, 17, 224235.

Gasquet, D., Ennih, N., Liegeois, J-P., Soulaimani, A. \& Michard, A. 2008. The Pan-African Belt. Continental Evolution. The Geology of Morocco. Springer, Berlin. Lecture Notes in Earth Sciences, 116, 33-64.

Gonçalves, P, Nicollet, C, \& Lardeaux, J-M. 2003. Finite strain patterns in Andriamena unit (northcentral Madagascar): evidence for late Neoproterozoic-Cambrian thrusting during continental convergence. Precambrian Research, 123, 135-157.

Goodenough, K.M., Thomas, R.J., De Waele, B., Key, R.M., Schofield, D.I., Bauer, W., Tucker, R., Rafahatelo, J-M., Rabarimanana, M., Ralison, A.V. \& Randriamananjara, T. 2010. Post-collisional magmatism in the central East African Orogen: the Maevarano Suite of north Madagascar. Lithos, 116, $18-34$.

Grantham, G.H., Maboko, M. \& Eglington, B.M. 2003. A review of the evolution of the Mozambique Belt and implications for the amalgamation and dispersal of Rodinia and Gondwana. In: YOSHIDA, M., WINDLEY, B.F., DASGUPTA, S. (eds.) Proterozoic East Gondwana: Supercontinent Assembly and Breakup. Geological Society of London, Special Publications, 206, 401-425.

Grégoire, V., Nédélec, A., Monié, P., Montel, J-M., Ganne, J., \& Ralison, B. 2009. Structural reworking and heat transfer related to the late-Panafrican Angavo Shear Zone of Madagascar. Tectonics, 477, 197-216.

Guérrot, C, Cocherie, A, \& Ohnenstetter, M. 1993. Origin and evolution of the west Andriamena Pan African mafic-ultramafic complexes in Madagascar as shown by $\mathrm{U}-\mathrm{Pb}$, $\mathrm{Nd}$ isotopes and trace elements constraints. Terra Abstracts, 5, 387.

Handke, M, Tucker, R D, \& Ashwal, L D. 1999. Neoproterozoic continental arc magmatism in westcentral Madagascar. Geology, 27, 351-354.

Hanson, R.E. 2003. Proterozoic geochronology and tectonic evolution of southern Africa. In: YOSHIDA, M., WINDLEY, B.F., DASGUPTA, S. (eds.) Proterozoic East Gondwana: Supercontinent Assembly and Breakup. Geological Society of London, Special Publication, 206, 427463.

Hottin, G. 1969. Les terrains cristallins du centre-nord et du nord-est de Madagascar. Document du Bureau Géologique de Madagascar, 178, 2 volumes, 1-192, 193-381.

Hottin, G.1976. Présentation et essai d'interprétation du Précambrien de Madagascar. Bulletin du Bureau de Recherches Géologiques et Minières, IV ( $2^{\text {nd }}$ Series), 117-153.

Jayananda, M., Chardon, D., Peucat, J.J., \& Capdevila, R. 2006. 2.61 Ga potassic granites and crustal reworking in the western Dharwar Craton, southern India: Tectonic, geochronologic and geochemical constraints. Precambrian Research, 150, 1-26.

Jacobs, J., \& Thomas, R.J. 2004. Himalayan-type indenter-escape tectonics model for the southern part of the late Neoproterozoic-early Palaeozoic East African-Antarctic orogen. Geology, 32, 721-724.

Jacobs, J., Fanning, C.M., Henjes-Kunst, F., Olesch, M. \& Paech, H.J. 1998. Continuation of the Mozambique Belt into East Antarctica: Grenville-age metamorphism and polyphase Pan-African high-grade events in Central Dronning Maud Land. Journal of Geology, 106, 385-406. 
Jacobs, J., Bauer, W. \& Fanning, C.M. 2003. Late Neoproterozoic/Early Palaeozoic events in central Dronning Maud Land and significance for the southern extension of East African Orogen into East Antarctica. Precambrian Research 126, 27-53.

Johnson, S.P., Rivers, T., \& De Waele, B. 2005. A Review of the Mesoproterozoic to early Palaeozoic magmatic and tectonothermal history of south-central Africa: implications for Rodinia and Gondwana. Journal of the Geological Society of London, 162, 433-450.

Johnson, S.P., De Waele, B., Evans, D., Banda, W., Tembo, F., Milton, J.A. \& Tani, K. 2007. Geochronology of the Zambezi supracrustal sequence, southern Zambia; a record of Neoproterozoic divergent processes along the southern margin of the Congo Craton. The Journal of Geology, 115, 355-374.

Jöns, N., Schenk, V, Appel, P, \& Razakamanana, T. 2005. Two-stage metamorphic evolution of the Bemarivo Belt (northern Madagascar): constraints from reaction textures and in situ monazite dating. European Geosciences Union 2005, Graz, Geophysical Research Abstracts, 7, 2.

Jöns, N, Schenk, V, Appel, P, \& Razakamanana, T. 2006. Two-stage metamorphic evolution of the Bemarivo Belt of northern Madagascar: constraints from reaction textures and in situ monazite dating. Journal of Metamorphic Geology, 24, 329-347.

Jourde, G. 1971. Essai de synthèse structurale et stratigraphique du Précambrien malagache. Compte Rendu Sociète Géologique France, 59-70.

Kabete, J., Groves, D., McNaughton, N., \& Dunphy, J. 2006. The geology, SHRIMP U-Pb geochronology and metallogenic significance of the Ankisatra-Besakay District, Andriamena belt, northern Madagascar. Journal of African Earth Sciences, 45, 87-122.

Kennedy, W.Q. 1964. The structural differentiation of Africa in the Pan-African (+/- 500 m.y.) Tectonic Episode. Annual Report on Scientific Results of the Research Institute of African Geology, University of Leeds, 8, 48-49.

Key, R.M., Liyungu, A.F., Njamu, F.J., Somwe, V., Banda, J., Mosley, P.N. \& Armstrong, R.A. 2001. The western arm of the Lufilian Arc in NW Zambia and its potential for copper mineralization. Journal of African Earth Sciences, 33, 503-528.

Kröner, A., Hegner, E., Collins, A.S., Windley, B.F., Brewer, T.S., Razakamanana, T. \& Pidgeon, R.T. 2000. Age and magmatic history of the Antananarivo Block, Central Madagascar, as derived from zircon geochronology and Nd isotopic systematics. American Journal of Science, 300, 251-288.

Kröner, A., Windley, B F, Jaeckel, P, Brewer, T S, \& Razakamanana, T. 1999a. Precambrian granites, gneisses and granulites from Madagascar: new zircon ages and regional significance for the evolution of the Pan-African orogen. Journal of the Geological Society, London, 156, 1125-1135.

Kröner, A., Windley, B F, Jaeckel, P, Collins, A. S, Brewer, T S, Nemchin, A, \& Azakamanana, T. 1999b. New zircon ages for Precambrian granites, gneisses and granulites from central and southern Madagascar: Significance for correlations in East Gondwana. Gondwana Research, 2, 351-352.

Li, Z.X., Bogdanova, S.V., Collins, A.S., Davidson, A., De Waele, B., Ernst, R.E., Fitzsimons, I.C.W., Fuck, R.A., Gladkochub, D.P., Jacobs, J., Karlstrom, K.E., Lu, S., Natapov, L.M., Pease, V., Pisarevsky, S.A., Thrane, K. \& Vernkovsky, V. 2008. Assembly, configuration, and beak-up history of Rodinia: A synthesis. Precambrian Research, 160, 179-210.

McCourt, S., Hanson, R. \& Key, R.M. 2006. Mesoproterozoic orogenic belts in southern and central Africa. Journal of African Earth Sciences, 46(5), v-xi.

Meert, J.G., 2003. A synopsis of events related to the assembly of eastern Gondwana. Tectonophysics, 362, 1-40.

Meert, J. G., Nédélec, A., Hall, C., Wingate, M. T. D. \& Rakotondrazafy, M. 2001. Paleomagnetism, geochronology and tectonic implications of the Cambrian-age Carion Granite, central Madagascar. Tectonophysics, 340, 1-21. 
Michard, A., Frizon, de Lamotte, D. Saddiqi, O \& Chalouan, A. 2008. An outline of the geology of Morocco. Continental Evolution; The Geology of Morocco.. Springer Berlin. Lecture Notes in Earth Sciences, 116, 1-31.

Moine, B, Chan Peng, C, \& Mercier, A. 2004. Rôle du fluor dans la formation des gisements d'émeraude de Mananjary (Est de Madagascar). C.R. Geoscience, 336, 513-522.

Nédélec, A., Stephens, W.E., \& Fallick, A.E. 1995. The Panafrican stratoid granites of Madagascar: alkaline magmatism in a post-collisional extensional setting. Journal of Petrology, 36, 1367-1391.

Nédélec, A., Ralison, B., Bouchez, J.L. \& Grégoire, V. 2000. Structure and metamorphism of the granitic basement around Antananarivo: a key to the Pan-African history of central Madagascar and its Gondwana connections. Tectonics, 19, 997-1020.

Pandey B.K., Gupta J.N., Sarma K.J. \& Sastry C.A.1997. Sm-Nd, Pb-Pb and Rb-Sr geochronology and petrogenesis of the mafic dyke swarm of Mahbubnagar, South India: implications for Paleoproterozoic crustal evolution of the Eastern Dharwar Craton. Precambrian Research, 84, 181196.

Paquette, J-L, \& Nédélec, A. 1998. A new insight into Pan-African tectonics in the East-West Gondwana collision zone by $\mathrm{U}-\mathrm{Pb}$ zircon dating of granites from central Madagascar. Earth and Planetary Science Letters, 155, 45-56.

Paquette, J L, Moine, B, \& Rakotondrazafy, M A F. 2003. ID-TIMS using the step-wise dissolution technique versus ion microprobe U-Pb dating of metamict Archean zircons from NE Madagascar. Precambrian Research, 121, 73-84.

Peucat, J.J., Mahabaleshwar, B. \& Jayananda, M. 1993. Age of younger tonalitic magmatism and granulite metamorphism in the South India transition zone (Krishnagiri area): comparison with older peninsular gneisses from the Gorur-Hassan area. Journal of Metamorphic Geology, 11, 879-888.

Pitfield, P.E.J., Macey, P.H., Smith, R.A., B. De Waele, B., Tucker, R.D., Schofield, D.I., Bauer, W., Armstrong, R.A., Yibas, B., Randriamananjara, T., Ralison, V., Rafahatelo, J-M. \& Rabarimanana, $M$. The nature of the Tsaratanana -Ampohipaky greenstone belts and their relationship with the Antananarivo migmatitic gneiss basement in central Madagascar. (in prep).

Porada, H. \& Berhorst, V. 2000. Towards a new understanding of the Neoproterozoic-Early Palaeozoic Lufilian and northern Zambezi Belts in Zambia and Democratic Republic of Congo. Journal of African Earth Sciences, 30, 727-771.

Raharimahefa, T. 2004. Structure, U-Pb geochronology and geochemistry of the Neoproterozoic crustal scale Angavo shear zone, central Madagascar. Ph.D. thesis, Saint Louis University, MO 63103, USA.

Schofield, D.I., Thomas, R. J., Goodenough, K. M., De Waele, B., Pitfield, P.E.J., Key, R. M., Bauer, W., Walsh, G. J., Lidke, D. J., Ralison, A.V., Rabarimanana, M., Rafahatelo, J. M. \&

Randriamananjara, T. In press. Geological evolution of the Antongil Craton, NE Madagascar.

Submitted to: Precambrian Research.

Stern, R.J. 1994. Arc assembly and continental collision in the Neoproterozoic East African Orogen: implications for the consolidation of Gondwanaland. Reviews of Earth and Planetary Sciences, 22, 319-351.2.

Thomas, R.J., De Waele, B., Schofield, D.I., Goodenough, K.M., Horstwood, M., Tucker, R.D., Bauer, W., Annells, R., Howard, K., Walsh, G., Rabarimanana, M., Rafahatelo, J-M., Ralison, A.V., \& Randriamanjara, T. 2009. Geological evolution of the Neoproterozoic Bemarivo Belt, northern Madagascar. Precambrian Research, 172, 279-300.

Torsvik, T.H., Smethurst, M.A., Meert, J.G., Van der Voo, R., McKerrow, W.S., Brasier, M.D., Sturt, B.A. \& Walderhaug, H.J. 1996. Supercontinent break-up and collision in the Neoproterozoic - a tale of Baltica and Laurentia. Earth Science Reviews, 40, 229-258. 
Tucker, R.D. Ashwal, L.D, Handke, M.J. \& Hamilton, M.A. 1997. A geochronologic overview of the Precambrian rocks of Madagascar: a record from the middle Archean to the Late Neoproterozoic. In: COX, R., ASHWAL, L.D. (eds.), Proceedings of the UNESCO-IUGS-IGCP 348/368 International Field Workshop on Proterozoic Geology of Madagascar, Gondwana Research Group. Rand Afrikaans University Miscellaneous Publication, 5, 99pp.

Tucker, R.D., Ashwal, L.D., Handke, M.J., Hamilton, M.A., Le Grange, M., \& Rambeloson, R.A. 1999a. U-Pb geochronology and isotope geochemistry of the Archean and Proterozoic rocks of northcentral Madagascar. Journal of Geology, 107, 135-153.

Tucker, R.D., Ashwal, L.D., Hamilton, M.A., Torsvik, T.H. \& Carter, L M. 1999b. Neoproterozoic silicic magmatism of northern Madagascar, Seychelles, and NW India: clues to Rodinia's assembly and dispersal. Geological Society of America, Abstracts with Programs, 31, 317.

Tucker, R.D., Kusky, T.M, Buchwaldt, R. \& Handke, M. J. 2007. Neoproterozoic nappes and superposed folding of the Itremo Group, west-central Madagascar. Gondwana Research, 12, 356-379.

Tucker, R.D., Roig, J-Y., Delor, C., Amelin, Y., Goncalves, P., Rabarimanana, M.H., Ralison, A.V. \& Belcher, R.W. 2010. Neoproterozoic Extension in the Greater Dharwar Craton: A Reevaluation of the "Betsimisaraka Suture" in Madagascar. Publication details to follow

Unrug, R. 1998. Rodinia to Gondwana: the geodynamic map of Gondwana supercontinent assembly. Journal of African Earth Sciences, 26, I-IX.

Vachette, M. \& Hottin, G. 1970. Age au strontium des granites d'Antongil et del'Androna (Nord-Est et Centre-Nord de Madagascar). Comptes Rendus Semaine Géologie de Madagascar, 73-76.

Wendorff, M. \& Key, R.M. 2009. The relevance of the sedimentary history of the Grand Conglomerat Formation (Central Africa) to the interpretation of the climate during a major Cryogenian glacial event. Precambrian Research, 172, 127-142.

Windley, B.F., Razafiniparany, A., Razakamanana, T. \& Ackermand, D. 1994. Tectonic Framework of the Precambrian of Madagascar and Its Gondwana Connections - a Review and Reappraisal. Geologische Rundschau, 83, 642-659. 
Figures

1. Location of the BGS-USGS-GLW study area in central and northern Madagascar and its position within the East African-Antarctica Orogen (EAAO); modified from Jacobs \&Thomas (2004).

2. An outline of the geology of the study area showing the main tectonic domains and main shear zones.

3. Simplified geological map (A) of the Antongil Craton, showing the main lithodemic units and $\mathrm{U}-\mathrm{Pb}$ dates. New geochronological ages shown as well as previously published $\mathrm{U}-\mathrm{Pb}$ dating (shown in italics) of Tucker et al. (1999) and Paquette et al. (2003). Inset map (B) shows the major Precambrian crustal terranes of Madagascar, modified after Collins 2006). $\mathrm{APT}=$ Andaparaty Thrust; $\mathrm{AB}-\mathrm{MO}=$ Anaboriana Belt - Manampotsy Belt; AN = Antongil Craton; $\mathrm{BE}=$ Bemarivo Belt; MA = Masora Craton; NT = Antananarivo Craton; $\mathrm{IT}=$ southern mobile belts including the Itremo Group; VO =Vohibory Unit. (from Schofield et al. in press)

4. An outline of the geology of the Masora Craton and surrounding Maroala Deformation Zone with the locations of isotopically dated rock samples. The $87.7 \pm 2.1$ Ma age in the extreme $\mathrm{SE}$ is from the Cretaceous volcanic cover over the Masora Craton.

5. An outline of the geology of the main outcrop of the Antananarivo Craton with the locations of isotopically dated rock samples.

6. An outline of the main supracrustal units of the Manampotsy Belt with the locations of isotopically dated rock samples.

7. Schematic representation of the stages recognised in north-eastern Madagascar in the breakup of Rodinia and the eventual formation of Gondwana. Section 1 highlights the early fragmentation of Rodinia into smaller continents. Section 2 shows the development of an arc terrane marginal to the Antananarivo Craton and subduction-related magmatism on the Masora Craton. 1 and 2 in this section refer to sediments and magmatic arc rocks in the Manampotsy Belt respectively. Sections 3-7 show the various stages in the Pan-African orogeny recorded in central and northern Madagascar with progressive amalgamation of the various continents and arc terranes and successive phases of granitic magmatism. 